\section{極値統計手法による最大局部 腐食深さ推定方法}

\author{
腐食防食協会 60-1 分科会
}

\section{1.はじめに}

60-1 装置材料の寿命予測 (II) 分科会では, 極值統計 手法による最大局部腐食深さ推定方法の解析手順を検討 し，推奨基準としてのマニュアルを作成した。

本方法は極值統計論を用いて，小面積の測定区画内の 最大局部腐食深さの測定結果を解析し，大面積の対象装 置・機器全体に括ける最大局部腐食深さ（極值）を推定 する手法である。

\section{2. 適用範囲}

このマニュアルは，局部腐食損傷を受けた，大面積の 装置・機器に抢ける最大局部腐食深さを, 小面積の測定 区画内の最大局部腐食深さデータから推定する方法扰よ びその手順を規定する。

\section{3. 最大局部腐食深さデータの採取}

\section{1 極値推定対象面皘の決定}

対象とする装置・機器の, 腐食環境に接する全表面積 を求め, これを極值推定対象面積， $S$ ，とする。ただし， 推定対象面積のどの部分からデータを採取しても, これ らがすべて同じ母集団からの標本として取り扱光ること が前提となる。したがって，採取位置によって，腐食環 境の差異等から同一母集団と見なせない恐れのある場合 は，とれぞれを別の母集団として取り扱う（層別する） 必要がある。

\section{2 測定区画の決定}

一定面積， $s$ ，の小区画を $N$ 個，対象面積から無作意 に選び出し，測定区画とする。

\section{3 データ採取}

適当な方法で局部腐食深さを測定し， $N$ 個の測定区画 から最大局部腐食深さを求める。一部の測定区画で局部 腐食が認められない場合, もしくはその深さが測定限界 以下である場合があるから，最大局部腐食深さデータが 得られた測定区画数を $n$ とする $(n \leqq N)$ 。これらの最大 值データを大きい順に並べ， $x_{1}, x_{2}, \cdots, x_{n}$ とする。

\footnotetext{
* 主查 柴田俊夫 (大阪大学工学部)
}

\section{4. 極值統計手法による解析}

\subsection{Gumbel 確率紙の作成}

局部腐食深さの分布が正規分布等の指数型分布に従ら とき，その最大值 (最大局部腐食深さ) の分布は Gumbel 分布に漸近する7)。变数, $x$, が Gumbel 分布に従うとき, その累積分布関数, $F(x)$, は次式の二重指数関数で与克 られる。

$$
\begin{aligned}
& F(x)=\exp [-\exp \{-(x-\lambda) / \alpha\}] \\
& \alpha: \text { 位置パラメータ }(=\text { 最頻值 }) \\
& \lambda: \text { 尺度パラメータ }
\end{aligned}
$$

規準化变数, $y$, ,

$$
y=(x-\lambda) / \alpha
$$

で定義すると，その累積分布関数は次式で与えられる。

$$
F(y)=\exp [-\exp (-y)]
$$

座標軸の一方に規準化変数, $y$,を目盛り, これに対応す る累積確率， $F(y)$, の値を同じ (平行な) 座標軸にいれ, もら一方の座標軸に $x$ の值を算術目盛りで示すことに よって, 図 1 亿示す Gumbel 確率紙が得られる。確率 紙上の直線が特定の Gumbel 分布を表す。 $y=0$ ，すなわ ち, $F(y)=0.368$ に対応する $x$ 座標が位置パラメータ， $\lambda$, の值を与克, 直線の勾配が尺度パラメータ， $\alpha ， の$ 值 を与える。眓の右側に目盛った $T$ は再帰期間と呼ばれる ものであって, 累積確率, $F(y)$, との関係は次式で示さ れる。

$$
F(y)=1-1 / T
$$

また， $T$ と $y$ との関係は， $T$, が大きい $(T \geqq 18)$ とき 次式で表される。

$$
y=\ln T
$$

なお, 再帰期間, $T$ は, ここでは対象面積と測定面積 との比;

$$
T=S / s
$$

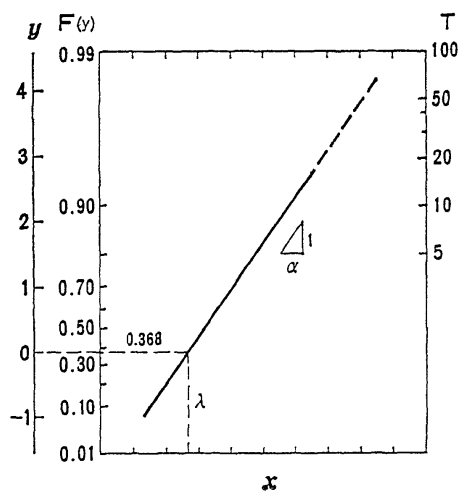

圀 1 Gumbel 確率紙の構成 
表 1 解析シート

\begin{tabular}{|l|l|l|l|l|l|}
\hline$i$ & $x_{i}$ & $f(x)$ & $y$ & $a_{i} x_{i}$ & $b_{1} x_{i}$ \\
\hline & & & & & \\
& & & & & \\
& & & & & \\
\hline
\end{tabular}

であって，極值推定示数と呼ばれるべきものである。

\subsection{Gumbel 確率紙へのプロット}

表 1 に示す解析シートを作成し, 最大局部腐食深さデ 一タを大きい順に並べた順位， $i ，$ と各順位に対応する最 大局部腐食深さデータ， $x_{\imath}$ ，の欄に数值を記入する。累 積確率， $F(y)$, すなわち Gumbel 確率紙の縦軸に対する プロット位置は, 次式の平均ランク法で決定する。

$$
F(y)=1-i /(N+1)
$$

$x_{i}$ と $F(y)$ (もしくは $y$ ) との関係を Gumbel 確率紙に プロットし，プロットがよい直線関係にあることを確認 する。

\section{3 分布パラメータの推定}

(1) 確率紙による推定

プロットに適当な直線を当てはめ, この直線上の $y=$ 0 に対応する $x$ 座標および直線の勾配から, 位置パラメ 一タおよび尺度パラメータの推定值， $\lambda$ および $\alpha$ を求め る。

（2）線型不偏推定子法による推定

確率紙上のプロットへの直線のあてはめ,すなわち分 布パラメータ推定には, Lieblein ${ }^{16)}-W_{\text {White }}{ }^{17)}$ の線型不偏 推定子法を用いるのが最も合理的である ${ }^{9), 15)}$ 。すなわち， 線型不偏推定子法では, 位置および尺度パラメータを次 式により推定する。

$$
\begin{aligned}
& \lambda=\sum a_{i} \cdot x_{i} \\
& \alpha=\sum b_{i} \cdot x_{i}
\end{aligned}
$$

係数, $a_{i}$ 抢よび $b_{i}$ は MVLUE 係数表 ${ }^{17),(8), 10), 15)}$ として 与えられている。そのらち $N=n$ の場合について表 2 に 拔粋しておく。これらの数值を用いて表 1 の解析シート の該当欄を計算することによって, 両分布パラメータを 合理的に推定できる。

\section{4 極值の推定}

全推定対象面積内に存在が期待される最大局部腐食深 さ (極值), $x_{m}$, は, 確率紙上でプロットにあてはめた直 線を再㷌期間, $T$, まで外挿したときの $x$ 座標の值に相 当し, 次式で求められる。

$$
x_{m}=\lambda+\alpha \ln T
$$

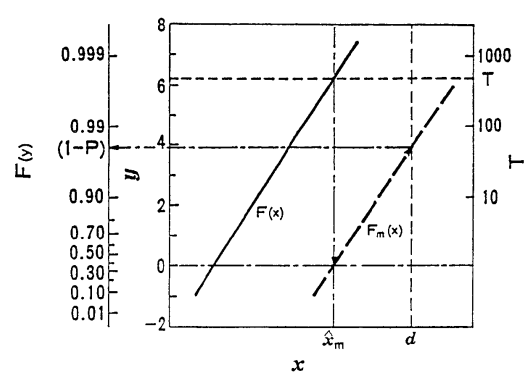

図 2 局部腐食貫通確率 $(P)$ の推定

\section{5 推定された極値の分布と貫通確率}

推定された極值, $x_{m}$, はそれ自体確率的な值であるか ら, その確率分布を考慮して極值を評価する必要がある。 Gumbel 分布, $F(x)$, からの $T$ 個の標本の最大值の分 布の累積分布関数, $F_{m}(x)$, は次式で与えられる。

$$
F_{m}(x)=\exp [-\exp \{-(x-[\lambda+\alpha \ln T]) / \alpha\}]
$$

すなわち, 極值, $x_{m}$, の確率分布はもとの分布と尺度パ ラメータが等しく，位置パラメータが $\alpha \ln T$ だけ大きい Gumbel 分布に従う。したがって, 対象材料の肉厚を $d$ として, 局部腐食の貫通確率, $P$, は次式で与えられる。 $P=1-\exp [-\exp \{-(d-[\lambda+\alpha \ln T]) / \alpha\}]$ なお，これらの関係は，Gumbel 確率紙上では図 2 で表 される。

\section{6 真の分布からの誤差の評価}

線型不偏推定子法で求めた分布は標本（データ）に対 して最も合理的にあてはめた分布であるが, 真の分布(標 本の母集団の分布）と一致している保証はないから, 真 の分布からの誤差を評価する必要がある。線型不偏推定 子法を用いれば誤差の分散, $V(x)$ は次式で与えられる。

$$
V(x)=\alpha^{2}\left\{A(N, n) y^{2}+B(N, n) y+C(N, n)\right\}
$$

係数, $A(N, n), B(N, n)$ および $C(N, n)$ は MVLUE 係 数表 ${ }^{3) \sim 5)}$ として与えられている。

\section{5. 報告}

次の事項を報告する。

(1) 対象装置・機器の供用期間, 使用条件, 材料の種 類・規格・熱処理, 肉厚等。

(2) 局部腐食形態。

（3）局部腐食深さ測定方法, 測定区間の位置, 推定対 象面積, 測定区画数および面積, 再帰期間。

(4) Gumbel 確率プロット。

(5) 位置パラメータ, 尺度パラメータ, 最大局部腐食 深さ (極値) の推定值。

（6）貫通確率。 
表 2 MVLUE 係数表 ${ }^{16)}$ (1)

\begin{tabular}{|c|c|c|c|c|c|c|c|c|c|}
\hline $\mathrm{N}$ & $n$ & 1 & $a_{1}$ & $b_{1}$ & $N$ & $n$ & 1 & $a_{1}$ & $b_{1}$ \\
\hline 2 & 2 & 1 & 0.08363 & 0.72135 & 8 & 8 & 1 & 0.03649 & 0.10194 \\
\hline \multirow[t]{2}{*}{2} & 2 & 2 & 0.91637 & -0.72135 & 8 & 8 & 2 & 0.05613 & 0.10807 \\
\hline & & & & & 8 & 8 & 3 & 0.07590 & 0.10273 \\
\hline 3 & 3 & 1 & 0.08797 & 0.37473 & 8 & 8 & 4 & 0.09714 & 0.08716 \\
\hline 3 & 3 & 2 & 0.25571 & 0.25582 & 8 & 8 & 5 & 0.12117 & 0.05893 \\
\hline \multirow[t]{2}{*}{3} & 3 & 3 & 0.65632 & -0.63054 & 8 & 8 & 6 & 0.15020 & 0.01112 \\
\hline & & & & & 8 & 8 & 7 & 0.18943 & -0.07577 \\
\hline 4 & 4 & 1 & 0.07138 & 0.24880 & 8 & 8 & 8 & 0.27354 & -0.39419 \\
\hline 4 & 4 & 2 & 0.15368 & 0.22392 & & & & & \\
\hline 4 & 4 & 3 & 0.26394 & 0.08590 & 9 & 9 & 1 & 0.03229 & 0.08839 \\
\hline \multirow[t]{2}{*}{4} & 4 & 4 & 0.51100 & -0.55862 & 9 & 9 & 2 & 0.04796 & 0.09437 \\
\hline & & & & & 9 & 9 & 3 & 0.06340 & 0.09197 \\
\hline 5 & 5 & 1 & 0.05835 & 0.18448 & 9 & 9 & 4 & 0.07957 & 0.08265 \\
\hline 5 & 5 & 2 & 0.10882 & 0.18166 & 9 & 9 & 5 & 0.09722 & 0.06557 \\
\hline 5 & 5 & 3 & 0.16761 & 0.13045 & 9 & 9 & 6 & 0.11736 & 0.03798 \\
\hline 5 & 5 & 4 & 0.24628 & 0.00653 & 9 & 9 & 7 & 0.14179 & -0.00649 \\
\hline \multirow[t]{2}{*}{5} & 5 & 5 & 0.41893 & -0.50313 & 9 & 9 & 8 & 0.17488 & -0.08520 \\
\hline & & & & & 9 & 9 & 9 & 0.24554 & -0.36924 \\
\hline 6 & 6 & 1 & 0.04887 & 0.14581 & & & & & \\
\hline 6 & 6 & 2 & 0.08352 & 0.14953 & 10 & 10 & 1 & 0.02893 & 0.07794 \\
\hline 6 & 6 & 3 & 0.12105 & 0.12672 & 10 & 10 & 2 & 0.04175 & 0.08355 \\
\hline 6 & 6 & 4 & 0.16562 & 0.07320 & 10 & 10 & 3 & 0.05419 & 0.08277 \\
\hline 6 & 6 & 5 & 0.22549 & -0.03599 & 10 & 10 & 4 & 0.06699 & 0.07702 \\
\hline \multirow[t]{2}{*}{6} & 6 & 6 & 0.35545 & -0.45927 & 10 & 10 & 5 & 0.08062 & 0.06606 \\
\hline & & & & & 10 & 10 & 6 & 0.09564 & 0.04867 \\
\hline 7 & 7 & 1 & 0.04184 & 0.12014 & 10 & 10 & 7 & 0.11287 & 0.02218 \\
\hline 7 & 7 & 2 & 0.06733 & 0.12586 & 10 & 10 & 8 & 0.13385 & $\cdot 0.01921$ \\
\hline 7 & 7 & 3 & 0.09375 & 0.11487 & 10 & 10 & 9 & 0.16231 & -0.09116 \\
\hline 7 & 7 & 4 & 0.12322 & 0.08734 & 10 & 10 & 10 & 0.22287 & -0.34783 \\
\hline ? & 7 & 5 & 0.15859 & 0.03619 & & & & & \\
\hline 7 & 7 & 6 & 0.20626 & -0.06070 & & & & & \\
\hline 7 & 7 & 7 & 0.30901 & 42370 & & & & & \\
\hline
\end{tabular}

表 2 MVLUE 係数表 ${ }^{16)}$ (2)

\begin{tabular}{rrrrr}
$y$ & $n$ & 1 & $a_{i}$ & $b_{i}$ \\
\hline 11 & 11 & 1 & 0.02618 & 0.06964 \\
11 & 11 & 2 & 0.03689 & 0.07483 \\
11 & 11 & 3 & 0.04716 & 0.07498 \\
11 & 11 & 4 & 0.05758 & 0.07138 \\
11 & 11 & 5 & 0.06849 & 0.06407 \\
11 & 11 & 6 & 0.08022 & 0.05246 \\
11 & 11 & 7 & 0.09323 & 0.03528 \\
11 & 11 & 8 & 0.10823 & 0.01003 \\
11 & 11 & 9 & 0.12652 & -0.02860 \\
11 & 11 & 10 & 0.15138 & -0.09487 \\
11 & 11 & 11 & 0.20412 & -0.32921 \\
& & & & \\
12 & 12 & 1 & 0.02389 & 0.06291 \\
12 & 12 & 2 & 0.03298 & 0.06767 \\
12 & 12 & 3 & 0.04163 & 0.06836 \\
12 & 12 & 4 & 0.05030 & 0.06612 \\
12 & 12 & 5 & 0.05927 & 0.06111 \\
12 & 12 & 6 & 0.06875 & 0.05305 \\
12 & 12 & 7 & 0.07902 & 0.04128 \\
12 & 12 & 8 & 0.09046 & 0.02455 \\
12 & 12 & 9 & 0.10367 & 0.00053 \\
12 & 12 & 10 & 0.11984 & -0.03566 \\
12 & 12 & 11 & 0.14183 & -0.09709 \\
12 & 12 & 12 & 0.18836 & -0.31284 \\
& & & & \\
13 & 13 & 1 & 0.02197 & 0.05733 \\
13 & 13 & 2 & 0.02979 & 0.06170 \\
13 & 13 & 3 & 0.03718 & 0.06270 \\
13 & 13 & 4 & 0.04453 & 0.06136 \\
13 & 13 & 5 & 0.05205 & 0.05786 \\
13 & 13 & 6 & 0.05990 & 0.05210 \\
13 & 13 & 7 & 0.06826 & 0.04371 \\
13 & 13 & 8 & 0.07737 & 0.03201 \\
& & & &
\end{tabular}

\begin{tabular}{ccccc}
$N$ & $n$ & 1 & $a_{1}$ & $b_{1}$ \\
\hline 13 & 13 & 9 & 0.08754 & 0.01584
\end{tabular} $\begin{array}{lllll}13 & 13 & 10 & 0.09932 & -0.00700\end{array}$ $\begin{array}{llllll}13 & 13 & 11 & 0.11376 & -0.04101\end{array}$ $\begin{array}{llllll}13 & 13 & 12 & 0.13342 & -0.09828\end{array}$ $\begin{array}{llllll}13 & 13 & 13 & 0.17492 & -0.29831\end{array}$

$\begin{array}{llllll}14 & 14 & 1 & 0.02032 & 0.05264\end{array}$ $\begin{array}{lllll}14 & 14 & 2 & 0.02713 & 0.05665\end{array}$ $\begin{array}{llllll}14 & 14 & 3 & 0.03353 & 0.05783\end{array}$ $\begin{array}{llllll}14 & 14 & 4 & 0.03985 & 0.05708\end{array}$ $\begin{array}{llllll}14 & 14 & 5 & 0.04626 & 0.05462\end{array}$ $\begin{array}{llllll}14 & 14 & 6 & 0.05289 & 0.05042\end{array}$ $\begin{array}{lllll}14 & 14 & 7 & 0.05987 & 0.04426\end{array}$ $\begin{array}{llllll}14 & 14 & 8 & 0.06733 & 0.03577\end{array}$ $\begin{array}{llllll}14 & 14 & 9 & 0.07548 & 0.02428\end{array}$ $\begin{array}{llllll}14 & 14 & 10 & 0.08462 & 0.00869\end{array}$ $\begin{array}{llllll}14 & 14 & 11 & 0.09522 & -0.01304\end{array}$ $\begin{array}{llllll}14 & 14 & 12 & 0.10823 & -0.04512\end{array}$ $\begin{array}{llllll}14 & 14 & 13 & 0.12597 & -0.09877\end{array}$ $\begin{array}{lllll}14 & 14 & 14 & 0.16331 & -0.28532\end{array}$

$\begin{array}{lllll}15 & 15 & 1 & 0.01889 & 0.04865\end{array}$ $\begin{array}{llllll}15 & 15 & 2 & 0.02489 & 0.05233\end{array}$ $\begin{array}{lllll}15 & 15 & 3 & 0.03048 & 0.05360\end{array}$ $\begin{array}{lllll}15 & 15 & 4 & 0.03598 & 0.05326\end{array}$ $\begin{array}{lllll}15 & 15 & 5 & 0.04153 & 0.05153\end{array}$ $\begin{array}{llllll}15 & 15 & 6 & 0.04722 & 0.04841\end{array}$ $\begin{array}{llllll}15 & 15 & 7 & 0.05314 & 0.04380\end{array}$ $\begin{array}{llllll}15 & 15 & 8 & 0.05940 & 0.03745\end{array}$ $\begin{array}{llllll}15 & 15 & 9 & 0.06613 & 0.02899\end{array}$ $\begin{array}{llllll}15 & 15 & 10 & 0.07349 & 0.01778\end{array}$ $\begin{array}{llllll}15 & 15 & 11 & 0.08177 & 0.00277\end{array}$ $\begin{array}{llllll}15 & 15 & 12 & 0.09138 & -0.01793\end{array}$
表 2 MVLUE 係数表 ${ }^{16)}$ (3)

\begin{tabular}{|c|c|c|c|c|c|c|c|c|c|}
\hline $\mathrm{N}$ & $n$ & 1 & $a_{1}$ & $b_{1}$ & $N$ & $n$ & 1 & $a_{1}$ & b \\
\hline 15 & 15 & 13 & 0.10320 & -0.04829 & 17 & 17 & 13 & 0.07640 & -0.00632 \\
\hline 15 & 15 & 14 & 0.11931 & -0.09877 & 17 & 17 & 14 & 0.08447 & -0.02522 \\
\hline \multirow[t]{2}{*}{15} & 15 & 15 & 0.15318 & -0.27361 & 17 & 17 & 15 & 0.09439 & -0.05262 \\
\hline & & & & & 17 & 17 & 16 & 0.10796 & -0.09779 \\
\hline 16 & 16 & 1 & 0.01765 & 0.04521 & 17 & 17 & 17 & 0.13636 & -0.25331 \\
\hline 16 & 16 & 2 & 0.02297 & 0.04860 & & & & & \\
\hline 16 & 16 & 3 & 0.02791 & 0.04991 & 18 & 18 & 1 & 0.01560 & 0.03958 \\
\hline 16 & 16 & 4 & 0.03275 & 0.04986 & 18 & 18 & 2 & 0.01987 & 0.04249 \\
\hline 16 & 16 & 5 & 0.03760 & 0.04865 & 18 & 18 & 3 & 0.02382 & 0.04379 \\
\hline 16 & 16 & 6 & 0.04254 & 0.04631 & 18 & 18 & 4 & 0.02765 & 0.04407 \\
\hline 16 & 16 & 7 & 0.04765 & 0.04279 & 18 & 18 & 5 & 0.03146 & 0.04352 \\
\hline 16 & 16 & 8 & 0.05299 & 0.03794 & 18 & 18 & 6 & 0.03531 & 0.04219 \\
\hline 16 & 16 & 9 & 0.05866 & 0.03153 & 18 & 18 & 7 & 0.03924 & 0.04006 \\
\hline 16 & 16 & 10 & 0.06477 & 0.02317 & 18 & 18 & 8 & 0.04329 & 0.03709 \\
\hline 16 & 16 & 11 & 0.07148 & 0.01227 & 18 & 18 & 9 & 0.04752 & 0.03318 \\
\hline 16 & 16 & 12 & 0.07902 & -0.00217 & 18 & 18 & 10 & 0.05197 & 0.02817 \\
\hline 16 & 16 & 13 & 0.08780 & -0.02193 & 18 & 18 & 11 & 0.05672 & 0.02182 \\
\hline 16 & 16 & 14 & 0.09860 & -0.05073 & 18 & 18 & 12 & 0.06186 & 0.01379 \\
\hline 16 & 16 & 15 & 0.11335 & -0.09841 & 18 & 18 & 13 & 0.06752 & 0.00354 \\
\hline \multirow[t]{2}{*}{16} & 16 & 16 & 0.14427 & -0.26299 & 18 & 18 & 14 & 0.07391 & -0.00984 \\
\hline & & & & & 18 & 18 & 15 & 0.08136 & -0.02974 \\
\hline 17 & 17 & 1 & 0.01656 & 0.04221 & 18 & 18 & 16 & 0.09053 & -0.05407 \\
\hline 17 & 17 & 2 & 0.02131 & 0.04535 & 18 & 18 & 17 & 0.10308 & -0.09700 \\
\hline 17 & 17 & 3 & 0.02571 & 0.04666 & 18 & 18 & 18 & 0.12930 & -0.24445 \\
\hline 17 & 17 & 4 & 0.03000 & 0.04681 & & & & & \\
\hline 17 & 17 & 5 & 0.03429 & 0.04598 & 19 & 19 & 1 & 0.01473 & 0.03726 \\
\hline 17 & 17 & 6 & 0.03863 & 0.04421 & 19 & 19 & 2 & 0.01860 & 0.03995 \\
\hline 17 & 17 & 7 & 0.04308 & 0.04149 & 19 & 19 & 3 & 0.02216 & 0.04123 \\
\hline 17 & 17 & 8 & 0.04771 & 0.03772 & 19 & 19 & 4 & 0.02561 & 0.04161 \\
\hline 17 & 17 & 9 & 0.05257 & 0.03276 & 19 & 19 & 5 & 0.02903 & 0.04127 \\
\hline 17 & 17 & 10 & 0.05774 & 0.02635 & 19 & 19 & 6 & 0.03247 & 0.04025 \\
\hline 17 & 17 & 11 & 0.06333 & 0.01815 & 19 & 19 & 7 & 0.03596 & 0.03859 \\
\hline 17 & 17 & 12 & 0.06948 & 0.00757 & 19 & 19 & 8 & 0.03955 & 0.03622 \\
\hline
\end{tabular}

表 2 MVLUE 係数表 ${ }^{18)}$ (4)

\begin{tabular}{rrrcr}
$N$ & $n$ & 1 & $a_{1}$ & $b_{1}$ \\
\hline 19 & 19 & 9 & 0.04326 & 0.03310 \\
19 & 19 & 10 & 0.04715 & 0.02911 \\
19 & 19 & 11 & 0.05125 & 0.02410 \\
19 & 19 & 12 & 0.05564 & 0.01784 \\
19 & 19 & 13 & 0.06039 & 0.01000 \\
19 & 19 & 14 & 0.06563 & 0.00006 \\
19 & 19 & 15 & 0.07155 & -0.01284 \\
19 & 19 & 16 & 0.07846 & -0.03020 \\
19 & 19 & 17 & 0.08698 & -0.05517 \\
19 & 19 & 18 & 0.09863 & -0.09608 \\
19 & 19 & 19 & 0.12295 & -0.23629
\end{tabular}

$\begin{array}{lllll}20 & 20 & 1 & 0.01396 & 0.03518\end{array}$ $\begin{array}{lllll}20 & 20 & 2 & 0.01748 & 0.03769\end{array}$ $\begin{array}{llllll}20 & 20 & 3 & 0.02071 & 0.03893\end{array}$ $\begin{array}{llllll}20 & 20 & 4 & 0.02383 & 0.03939\end{array}$ $\begin{array}{llllll}20 & 20 & 5 & 0.02692 & 0.03920\end{array}$ $\begin{array}{llllll}20 & 20 & 6 & 0.03001 & 0.03844\end{array}$ $\begin{array}{llllll}20 & 20 & 7 & 0.03314 & 0.03712\end{array}$ $\begin{array}{lllll}20 & 20 & 8 & 0.03634 & 0.03522\end{array}$ $\begin{array}{llllll}20 & 20 & 9 & 0.03964 & 0.03269\end{array}$ $\begin{array}{llllll}20 & 20 & 10 & 0.04307 & 0.02947\end{array}$ $\begin{array}{llllll}20 & 20 & 11 & 0.04665 & 0.02545\end{array}$ $\begin{array}{llllll}20 & 20 & 12 & 0.05045 & 0.02047\end{array}$ $\begin{array}{llllll}20 & 20 & 13 & 0.05452 & 0.01432\end{array}$ $\begin{array}{llllll}20 & 20 & 14 & 0.05894 & 0.00668\end{array}$ $\begin{array}{llllll}20 & 20 & 15 & 0.06381 & -0.00296\end{array}$ $\begin{array}{llllll}20 & 20 & 16 & 0.06931 & -0.01540\end{array}$ $\begin{array}{llllll}20 & 20 & 17 & 0.07576 & -0.03208\end{array}$ $\begin{array}{llllll}20 & 20 & 18 & 0.08369 & -0.05600\end{array}$ $\begin{array}{llllll}20 & 20 & 19 & 0.09457 & -0.09508\end{array}$ $\begin{array}{lllll}20 & 20 & 20 & 0.11721 & -0.22875\end{array}$ \begin{tabular}{ccccc} 
& $n$ & 1 & $a_{1}$ & $b_{1}$ \\
\hline 21 & 21 & 1 & 0.01326 & 0.03326
\end{tabular} $\begin{array}{llllll}21 & 21 & 2 & 0.01648 & 0.03567\end{array}$ $\begin{array}{llllll}21 & 21 & 3 & 0.01942 & 0.03687\end{array}$ $\begin{array}{lllll}21 & 21 & 4 & 0.02227 & 0.03737\end{array}$ $\begin{array}{llllll}21 & 21 & 5 & 0.02507 & 0.03730\end{array}$ $\begin{array}{llllll}21 & 21 & 6 & 0.02786 & 0.03674\end{array}$ $\begin{array}{llllll}21 & 21 & 7 & 0.03071 & 0.03569\end{array}$ $\begin{array}{llllll}21 & 21 & 8 & 0.03355 & 0.03416\end{array}$ $\begin{array}{lllll}21 & 21 & 9 & 0.03651 & 0.03210\end{array}$ $\begin{array}{llllll}21 & 21 & 10 & 0.03956 & 0.02946\end{array}$ $\begin{array}{llllll}21 & 21 & 11 & 0.04274 & 0.02619\end{array}$ $\begin{array}{llllll}21 & 21 & 12 & 0.04607 & 0.02215\end{array}$ $\begin{array}{llllll}21 & 21 & 14 & 0.05339 & 0.01120\end{array}$ $\begin{array}{llllll}21 & 21 & 15 & 0.05750 & 0.00375\end{array}$ $\begin{array}{llllll}21 & 21 & 16 & 0.06209 & -0.00557\end{array}$ $\begin{array}{llllll}21 & 21 & 17 & 0.06719 & -0.01762\end{array}$ $\begin{array}{llllll}21 & 21 & 18 & 0.07323 & -0.03365\end{array}$ $\begin{array}{llllll}21 & 21 & 19 & 0.08067 & -0.05660\end{array}$ $\begin{array}{llllll}21 & 21 & 20 & 0.09083 & -0.09401\end{array}$ $\begin{array}{llllll}21 & 21 & 21 & 0.11199 & -0.22176\end{array}$ $\begin{array}{llllll}21 & 21 & 13 & 0.04961 & 0.01724\end{array}$ 


\section{[解説]}

\section{1. マニュアル作成の背景および適用範囲}

Evans $^{1)}$ の指摘したように, 腐食現象, とくに局部腐 食現象は本質的に確率的性質を有するので, 局部腐食損 傷の定量的評価には, 確率統計的なアプローチの導入が 必要とされる2) 4)。

1950 年代の $\mathrm{Aziz}^{5)}$ 抢よび Eldledge ${ }^{\text {()) }}$ の先駆的な研究 以来, Gumbel ${ }^{7)}$ の極值統計論に基づいて, 局部腐食深 さの最大值 (極值) を推定する, いわゆる極值推定法2),8 が多くの局部腐食系について検討されてきた。

わが国では, 本協会の腐食現象の確率的評価研究会 （世話人：增子昇 1980-81）拈よび装置材料の寿命予測分 科会 (主查: 小若正倫 1981-83) の活動を中心に, 極值解 析法の適用に関する検討が進み，その成果の一つとして 本手法の入門書が刊行された

適用例の增加とともに, 本方法の適用限界や問題点 も 明らかになってきたが，それとともに，一般の技術者が 本方法を適用する場合に最小限必要とされる解析手順を 簡潔にまとめたマニュアルが要望されるようになった。

以上の背景のもとに装置材料の 寿命予測 (II) 分科会 (主査：柴田俊夫 1985-87) では,これまでの適用経験を ふま兄て, 共通の手順を検討し, 極值解析法のマニュア ルを作成した。

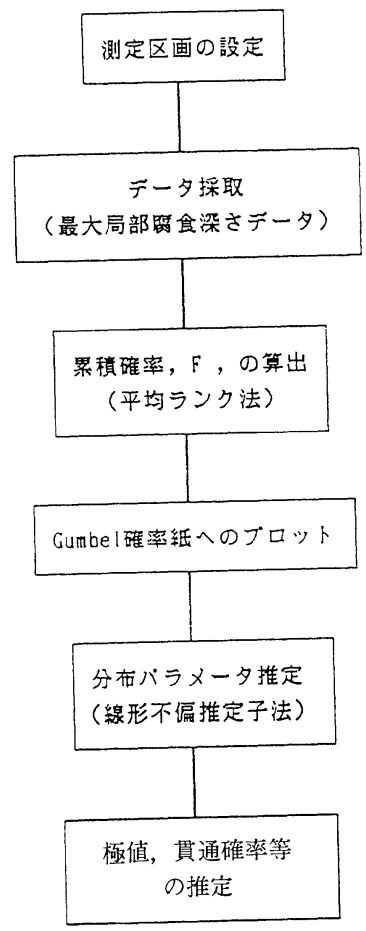

付図 1 極值統計手法による最大局部腐食深さ推定 手順
本マニュアルは実装置・機器の供用中検査時における 適用を念頭においているため, 適用範囲をこれに限って いるが，他に実験室加速試験データの解析への適用も可 能である。付図 1 に, 本マニュアルに従って, 最大腐食 深さを推定する場合の手順を示したが，マニュアル中に は述べられていない，具体的に適用する場合の問題点の いくつかを解説として以下に付した。

\section{2. 最大局部腐食深さデータの採取}

本手法を実際適用する場合には，測定区画面積， $s$, 拉よびその個数， $N$ ，をどのように決定するかが問題と なる。面積および個数が小さくてすめばこれにこした ことはないが，それだけ極值推定の精度が低下すること となる。

推定精度と $s, N$ の関係を考光るために，まずマニュ アル中に述べられてある式 (5)，(6) 和よび (13) を再掲す る。

$$
\begin{gathered}
y=\ln T \\
T=S / s \\
V(x)=\alpha^{2}\left\{A(N, n) y^{2}+B(N, n) y+C(N, n)\right\}
\end{gathered}
$$

式 (5) から，Tが大きくなるほど $y$ が大きくなる。また，

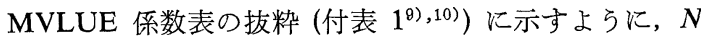

\section{付表 1 MVLUE 係数表抜粋 16,10 )}

\begin{tabular}{rrrrr}
$N$ & $n$ & $A(N, n)$ & $B(N, n)$ & $C(N, n)$ \\
\hline 5 & 5 & 0.16665 & 0.06798 & 0.23140 \\
10 & 10 & 0.07157 & 0.04395 & 0.11297 \\
15 & 15 & 0.04534 & 0.03111 & 0.07481 \\
20 & 20 & 0.03313 & 0.02397 & 0.05593 \\
25 & 25 & 0.02609 & 0.01947 & 0.04466 \\
30 & 30 & 0.02151 & 0.01638 & 0.03717 \\
35 & 35 & 0.01829 & 0.01414 & 0.03183 \\
40 & 40 & 0.01591 & 0.01243 & 0.02784 \\
45 & 45 & 0.01407 & 0.01103 & 0.02473
\end{tabular}

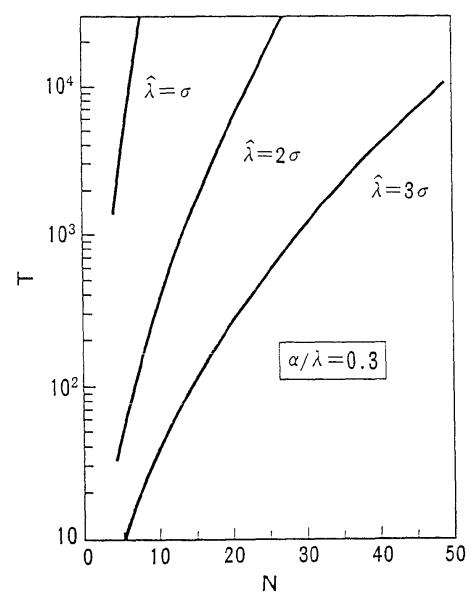

付図 2 測定区画数, $\mathrm{N}$, と再帰期間, $\mathrm{T}$, の適正条 件 
が大きくなるほど $A(N, n), B(N, n)$ および $C(N, n)$ が小 さくなる。したがって, 極值, $x_{m}$, の推定の信頼度を上げ るためには, 測定区画数, $N$, を大きくするか, あるいは 測定区画の面積を大きくして，y= $\ln T$ を小さくする必 要がある。したがって，できる限り $N$ を大きくし，かつ $y=\ln T$ を小さくするのが望ましい。一方, 少ないサン プリング数から全域の極值を推定できる点に極值統計手 法適用の最大のメリットがあることからは，できるだけ $N$ を小さく，から $y=\ln T$ を大きくしたい。これらの観 点から適正な $N$ および $T$ の選定指針の確立への要望は 強いが, 現状では適正選定指針が示されていない早ので, 基準化できなかった。ここでは, 参考のために, 選定指 針に対する一提案11),12),18)を紹介して扰く。

推定すべき極值, $x_{m}$,の誤差の標準偏差, $\sigma_{x m}$, は式 (13) の $V(x)$ の平方根であるから， $\alpha$ に依存する。したがっ て， $\alpha$ あるいは $\alpha / \lambda$ があらかじめ分かっていなければ $\sigma_{x m}$ を評価できない。本分科会のアンケート解析結果 ${ }^{14}$ によると, 淡水あるいは土壤環境の炭素鋼の局部腐食で は $\alpha / \lambda=0.3$ 附近の例が最も多いことから, ここでは $\alpha /$ $\lambda=0.3$ として, $x_{m}$ の誤差の標準偏差, $\sigma_{x m}$, と分布の最 頻值; $\lambda$, との関係が $\lambda=m \sigma$ となるような $N$ と $T$ との 組合せを, 式 (5), (6), (13) 和よび MVLUE 係数表から 求めた結果を, $m=1,2$ および 3 の場合について付図 2 に示す。これにより, 例光ば $\lambda=3 \sigma$ の場合, すなわち推 定する $x_{m}$ の䛊差の標準偏差を測定された最大值データ (の最頻值)の $1 / 3$ 程度に抑兄るためには, $T=1000$ に対 して $N=30$ 程度が必要となる。

付図 2 に見るように，一般に $T$ を小さくするよりも $N$ を大きくすることのほうが効果的である。したがって 総測定面積を一定とすれば, 測定区画面積を小さくして $N, T$ ともに大きくするほうが有利であると言える。し かしながら，測定区画面積をあまり小さくすると別の問 題を生じる。すなわち, 指数型基本分布からの $k$ 個の標 本の最大值の分布が, $k$ が大きくなると Gumbel 分布に 漸近することから, 測定区画面積をあまり小さくして, $k$ (各測定区画に损ける局部腐食発生数に相当)を小さく してしまうと, Gumbel 分布に近似して解析するといら 大前提が崩れてしまら恐れがある。適正な $k$ について も指針がないのが現状である。数学的厳密さからはかな り大きい $k$ が要求されるが, 実用上は $k=20$ 程度で十 分近似できているよらである。

\section{3. 極值統計手法による解析}

本マニュアルでは Gumbel 確率紙の作成方法を規定 したが、この確率紙は極值確率紙として市販されている ので,これを使用してもよい。

また，確率紙の縦軸に対するプロット位置の決定方法
として，平均ランク法を規定している。この方法は必ず しも最も合理的な方法とは言えないが，一般的に使用さ れている方法であることから，これを規定した。

分布パラメータを推定する方法は種々あるが，線形不 偏推定子法 ${ }^{15), 91}$ とよるのが最も合理的であって, Gumbel 分布に対しては Lieblein ${ }^{18)}$-White ${ }^{17)}$ の MVLUE 法を用いるのがよい。ただし，これをで MVLUE 係数 表は $N=23^{9)}$ までしか与兄られていなかったが，柘植 ${ }^{10)}$ によって $N=45$ まで計算されたのでこれを用いるとよ い。45 以上の $N$ に対しては最尤法"五るいはモーメン ト法 ${ }^{15)}$ をいなければならない。

\section{4. 適用 例}

ここでは本マニュアルの適用例を，以下の例題により 示す。

\section{[例題] 石油タンク底板の孔食}

石油ストレージタンク（炭素鋼製，20 年使用）底板 に, $50 \times 50\left(\mathrm{~cm}^{2}\right)$ の測定区画を任意に 9 䈏所選び, 最 大孔食深さを測定した。底板全表面積は $125 \mathrm{~m}^{2}$, 板厚は $6 \mathrm{~mm}$ である。得られた最大孔食深さデータを以下に示 す。

$1.6,2.0,1.8,2.5,1.3,0.8,2.3,1.0,1.5(\mathrm{~mm})$ (出光石油化学/石本氏泣る)

付表 2 最大孔食深さデータの解析

\begin{tabular}{|c|c|c|c|c|c|c|}
\hline i & $x_{i}$ & a (i) & b (i) & $a(i) \cdot \times i$ & $b(i) \cdot x i$ & $\mathrm{~F}$ \\
\hline 1 & 2.5 & .03229 & .08839 & 0.0807 & 0.221 & .90 \\
\hline 2 & 2.3 & .04796 & .09437 & 0.110 & 0.217 & .80 \\
\hline 3 & 2.0 & .06340 & .09197 & 0.127 & 0.184 & .70 \\
\hline 4 & 1.8 & .07957 & .08265 & 0.143 & 0.149 & .60 \\
\hline 5 & 1.6 & .09722 & .06557 & 0.156 & 0.105 & .50 \\
\hline 6 & 1.5 & .1174 & .03798 & 0.176 & 0.0570 & .40 \\
\hline 7 & 1.3 & .1418 & -.006486 & 0.184 & -0.00843 & .30 \\
\hline 8 & 1.0 & .1749 & -.08520 & 0.175 & -0.0852 & .20 \\
\hline 9 & 0.8 & .2455 & -.3692 & 0.196 & -0.295 & .10 \\
\hline & & 合 & 計 & 1.35 & 0.544 & \\
\hline
\end{tabular}

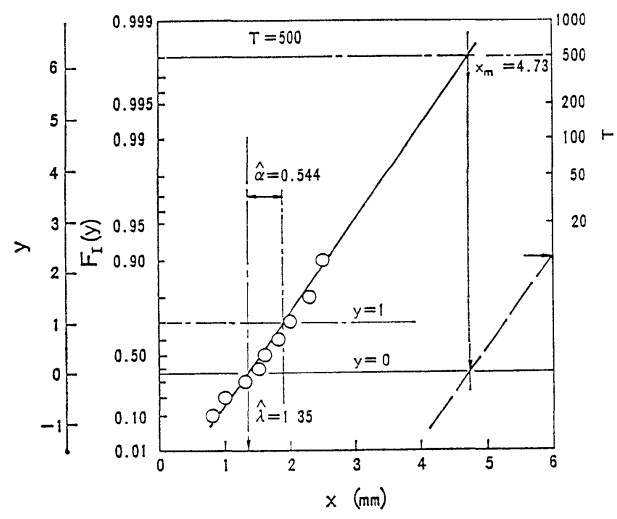

付図 3 最大孔食深さデータの Gumbel 確率プロ ット 
解析手順に従って, データを大きい順に並べ, 解析シー トに書き込むことにより，付表 2 を得る。本データは $N=n=9$ であるから, これに対応する MVLUE 係数表 を用いて， $a_{i} x_{i}$ および $b_{i} x_{i}$ を計算し，それぞれの総和を 求めることにより, 位置㘧よび尺度パラメータの推定值 を，それぞれ $\lambda=1.35(\mathrm{~mm})$ 预よび $\alpha=0.544(\mathrm{~mm})$ と して求めることができる。

全推定対象面積内に存在が期待される最大孔食深さ (極值), $x_{m}$ ，は，再帰期間を $T=125 / 0.25=500$ として，

$$
x_{m}=\lambda+\alpha \ln T=4.73(\mathrm{~mm})
$$

となる。またマニュアル中の式 (11) により, 孔食貫通確 率 $P=0.093$ が求められる。Gumbel 確率紙へのプロッ 卜例を付図 3 に示した。

な特，MVLUE 係数表とマニュアル中の式 (13) とに より， $x_{m}$ の誤差の標準偏差を推定すると, $1.02(\mathrm{~mm})$ となる。これは必ずしも小さな值ではないが, 本例題の 条件では極值推定の精度はこの程度であることを銘記す べきである。

\author{
担当委員 柴田俊夫 (大阪大学) \\ 明石正恒 (石川島播磨重工) \\ 柘植宏之 (住友金属) \\ 池松敬介 (日本防蝕) \\ 中島博志 (鹿島建設)
}

\section{文献}

1) U. R. Evans, P. B. Mears \& P.E. Queneau:
Engineering, 136, 689 (1933).

2）增子 昇: 防食技術, 21, 347 (1972).

3）柴田俊夫：防食技術, 27, 23 (1978).

4）柴田俊夫：金属表面技術, 31, 336 (1980).

5) P. M. Aziz: Corrosion, 12, $495 \mathrm{t}$ (1956).

6) G. G. Eldledge: ibid., 13, $51 \mathrm{t}$ (1957).

7) E. J. Gumbel: "Statistics of Extremes", Colombia Univ. Press (1958).

8）石川雄一：防食技術, 28, 278 (1979).

9）腐食防食協会編：“装置材料の寿命予測入門一極 值統計の腐食への適用一”, 丸善 (1984).

10) 柘植宏之: 私信, N=42 宗で MVLUE 法係数 表は極值解析パッケージ (EVAN, 丸善より発売 予定) に含まれている。

11）正村克身：第 58 回腐食防食シンポジゥム資料, p. 1，腐食防食協会 (1984).

12） 60-1 寿命予測 (II) 分科会報告：防食技術, 37, 703 (1988).

13）明石正恒：第 5 回設備診断技術シンポジウム, 日 本プラントメンテナンス協会, p. B4-1 (1985).

14）明石正恒: 日本機械学会第 644 回講習教材, p. 67 (1987).

15）加瀬滋男編著：“信頼性データのまとめ方一二重 指数分布の活用法一”, オーム社 (1983).

16) J. Lieblein: "A New Method of Analyzing Extreme-Value Data", Nat. Advisory Committee for Aeronautics, Tech. Note, No. TN-3053 (1954).

17) J. S. White: Ind. Math., 14, 21 (1964). 